\title{
An Interdisciplinary Approach to Teachers' Voice Disorders and Psychosocial Working Conditions
}

\author{
Rosa M. Bermúdez de Alvear ${ }^{\mathrm{a}}$ Ginés Martínez-Arquero ${ }^{\mathrm{d}} \quad$ F. Javier Barón ${ }^{\mathrm{b}}$ \\ Antonio Hernández-Mendo ${ }^{c}$

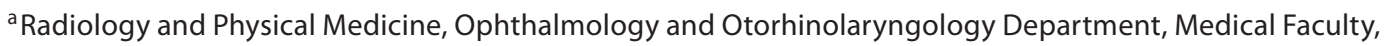 \\ bPreventive Medicine Department, Medical Faculty, and 'Psychosocial Department, Faculty of Psychology, \\ Málaga University, and d Otorhinolaryngology Department, University Hospital Carlos Haya, Málaga, Spain
}

\section{Key Words}

Voice abuse - Vocal complaints - Teachers $\cdot$ Occupational health $\cdot$ Occupational voice disorders $\cdot$ Voice disorders, prevalence $\cdot$ Psychosocial risk factors

\begin{abstract}
Objectives: The goals of this epidemiological paper are focused on studying teachers' vocal complaints, their voice pattern, and the impact of voice disorders on psychosocial working conditions. Patients: A representative stratified random sample of 282 teachers from kindergartens and elementary schools was studied. Two types of self-report questionnaires were applied: an inquiry about teachers' occupational voice profile, and the adapted Spanish version of the Copenhagen Psychosocial Questionnaire (ISTAS-21). Pearson's $\chi^{2}$ test was performed to search for statistical associations. Results: $62.7 \%$ of subjects were experiencing occupational voice disorders; these teachers showed significantly worse psychosocial conditions than their healthy voice colleagues. Conclusions: Occupational voice disorders affect more than $60 \%$ of teachers and have an impact on their psychosocial working conditions. Interdisciplinary work is essential to shed light on these multifactor mechanisms and effects.

Copyright $\odot 2010$ S. Karger AG, Basel
\end{abstract}

\section{Introduction}

Nowadays voice disorders in school teachers should not be conceptualized as individual problems but as occupational hazards [1]. Therefore, analyzing the interaction between the multifaceted risk factors which affect teachers' work must be sine qua non for the assessment, treatment and prevention of their occupational voice disorders [2-6].

In teachers' working context, psychological factors may be associated with muscle strain added to the professional vocal load [7]. It is well known that voice hyperfunction and stress share a common physiological pathway since both of them result in increased muscular tension on the chest, shoulders and neck region [8-10]. In this regard, early experimental studies during the eighties [11] evidenced that stress was connected with objective parameters of strained vibratory features such as raised fundamental frequency $\left(\mathrm{F}_{0}\right)$, sound level and spectral characteristics. Clinical studies have also proven that voice disorders may become chronic or resistant to treatment if certain psychological factors are present [12-14], and in a recent cross-sectional study perceived stress or depression were more frequently associated with muscle tension dysphonia than with other types of voice disor-

\section{KARGER}

Fax +41613061234

E-Mail karger@karger.ch

www.karger.com
(C) 2010 S. Karger AG, Basel

1021-7762/10/0622-0024\$26.00/0

Accessible online at:

www.karger.com/fpl
Rosa M. Bermúdez de Alvear, Radiology and Physical Medicine Ophthalmology and Otorhinolaryngology Department

Medical Faculty, Boulevard Pasteur Av. 32, Teatinos Campus, Málaga University ES-29071 Málaga (Spain)

Tel. +34 605688 490, Fax +34952 131 630, E-Mail bermudez@uma.es 
ders [15]. Indeed there is a considerable body of evidence connecting stress, muscle strain and voice disorders.

From the psychosocial perspective, prospective studies have shown that certain models of work relations are associated with occupational stress and health problems [16-18]. Nonetheless, occupational voice problems have not yet been assessed in the framework of the conceptual psychosocial models of employment. In fact, the variety of employment hazards which may contribute to vocal health problems needs to be comprehensively approached in teachers $[5,6]$. This issue seems especially appropriate now that voice problems have recently been legislated as occupational diseases for certain types of jobs in some European countries such as Spain [19].

The epidemiological study we are now introducing belongs to a larger cross-sectional work which was focused on kindergarten and elementary school teachers' voice problems analyzed from multidisciplinary perspectives. Its main objective was to relate teachers' vocal pattern, their vocal complaints and voice disorders to other factors such as environmental risk factors for voice use, absenteeism, health services demands, teachers' quality of life, and their psychosocial conditions. Self-report questionnaires were used to approach these multidimensional repercussions of teachers' professional voice use, as in other studies which have assessed the magnitude of a health problem that affects a large group of the population [20].

The present paper aims at analyzing the interactions between teachers' professional voice use, their vocal disorders, and psychosocial working conditions.

\section{Method}

\section{Subjects and Sampling Procedures}

A representative stratified sample of 282 teachers from 51 kindergartens and elementary schools was surveyed by self-report questionnaires during the academic year 2004/2005. Volunteers were randomly selected from the total teachers' census in the Malaga City District (Andalusia, Spain), which consisted of 2,174 subjects and 82 public schools.

In order to obtain a proportionally distributed sample throughout the city area, this population was homogeneously divided into six geographical strata with similar numbers of teachers (south, south-west, west, north, north-east, and east). The different levels of the pupils' standards of living were equally represented in every stratum.

Before the survey, the Head Office of Human Resources in the Ministry of Education of the Regional Andalusia Government was informed about this research framework and goals. After obtaining consent, the Local Office of Education was asked for the $2004 / 2005$ census of currently employed, fulltime teachers in kin- dergartens and primary schools. Subsequently headmasters of 63 schools were approached by phone and requested to inform their teachers about the participation in the study. As a result of this initial contact, 879 teachers volunteered to take part in the study; thereafter the corresponding questionnaires were distributed among 51 schools. The surveys were forwarded to every school together with a brief explanation about the study background and its objectives, as well as instructions to complete the forms. All the participants signed an informed consent to allow their data to be confidentially treated for research purposes.

The questionnaires were returned anonymously and collected personally by the authors at every school. Finally a $32 \%$ participation rate was reached which included $13 \%$ of the total teaching population in this city district.

\section{Materials}

In this study, two types of self-report questionnaires were employed to collect data about occupational voice problems and psychosocial risk factors of work.

From a previous survey [9] whose items were based on the literature $[3,12,21-26]$ and clinical experience, two types of questions were selected to assess the vocal use and occupational voice disorders in this study (see Appendix 1). The selected items were those regarding frequency of vocal symptoms and perceived effort during professional voice use.

Data related to psychosocial risk factors were collected by the ISTAS-21 [27], which is an adapted Spanish version of the Copenhagen Psychosocial Questionnaire [28]. This instrument was designed to be used in any type of work context to measure the organizational, social, and psychological characteristics of jobs which can affect workers' health. It has been validated in the Spanish population and is recommended by experts in occupational health and safety [29-31]. In this study, the medium version of this questionnaire was employed since all of its variables are supported by epidemiological studies (http://www.ccoo.es/ csccoo). In brief, the ISTAS-21 explores 21 psychosocial dimensions of work by a series of 124 distinct scales. These psychosocial dimensions can be categorized into two types of indicators: those which measure the exposure to psychosocial risk factors of the job, and those which assess the psychosomatic effects that can be derived from work conditions (see Appendix 2).

Exposure indicators in the ISTAS-21 consist of four comprehensive groups of psychosocial dimensions: 'psychological demands', 'active work and skill development', 'social support and superiors' leadership quality', and 'work insecurity'. The psychological demands category is based on Karasek's 'demand-control' model [16, 32]; it represents the negative aspects of employment and refers to quantitative as well as to qualitative demands (e.g. the time available to achieve work; the situations that oblige workers to delay it; the emotional impact of work; its cognitive requirements, and its sensorial demands) [33]. The active work and skill development group of factors are also conceptually compatible with the demand-control pattern, but they refer to control over working time and task content, and therefore they assess the positive aspects of the job $[16,32]$. The social support and superiors' leadership quality dimensions [34] are also related to the demandcontrol model, but they represent those factors that can compensate work demands. Finally, the work insecurity group of measures are partially consistent with Siegrist's 'effort-reward' pattern $[17,35]$; they rate the balance between the employees' 
Table 1. Subjects' age and gender distribution

\begin{tabular}{lllllll}
\hline & \multicolumn{2}{l}{ Age groups } & & & Total \\
\cline { 2 - 6 } & $<26$ & $26-35$ & $36-45$ & $46-55$ & $>55$ & \\
\hline Male teachers & $1(1.4)$ & $6(8.3)$ & $16(22.2)$ & $32(44.4)$ & $17(23.6)$ & $72(100.0)$ \\
Female teachers & $8(3.8)$ & $34(16.2)$ & $63(30.0)$ & $81(38.6)$ & $24(11.4)$ & $210(100.0)$ \\
\hline Total & $9(3.2)$ & $40(14.2)$ & $79(28.0)$ & $113(40.1)$ & $41(14.5)$ & $282(100.0)$ \\
\hline
\end{tabular}

Figures are numbers, with percentages in parentheses.

commitment and other types of work compensations such as esteem, promotion prospects, or salary.

Effect indicators in the ISTAS-21 include four groups of psychosomatic manifestations: 'perceived health state', 'vitality', 'stress symptoms', and 'job satisfaction'. These factors do not belong to the original Copenhagen Psychosocial Questionnaire, but they have been selected from other validated tests and gathered into the Spanish instrument. The perceived health state category comes from the SF-36 [36] and involves both general and mental health dimensions. The three other types of psychosomatic measures belong to the Stress Profile Questionnaire [37].

\section{Method and Statistical Analysis}

Pearson's $\chi^{2}$ test was performed to assess relations between variables. Firstly, associations between vocal effort and vocal complaints were studied. Subsequently, the sample was divided into two groups regarding the presence or absence of voice problems, and thus the unhealthy voice (UV) versus the healthy voice (HV) groups of teachers were obtained. The UV group included subjects indicating vocal effort together with more than two frequent voice complaints at the end of their working day. The presence of vocal symptoms was considered relevant for voice problems if they occurred 'quite frequently' or 'always'. On the other hand, the HV group included those without any vocal problems, i.e. those who evidenced less than two frequent vocal complaints at the end of their working day, and/or showed no vocal strain at all.

Finally Pearson's $\chi^{2}$ test was also applied to find out significant links between the UV group and psychosocial working conditions. The significance level was set at $\mathrm{p}<0.050$. The SPSS 15.0 version for Windows was employed to analyze data.

\section{Results}

\section{General Epidemiological Data}

The sample included 282 teachers; $74.6 \%$ of them were female while $25.4 \%$ were male. The age of the participants ranged from 23 to 63 years, with an average of 44 years $(\mathrm{SD}=9.8)$. The number of subjects in each age group was found to be similar to that of the city district census (table 1).

\section{Prevalence of Voice Complaints}

At the end of a working day, more than $50 \%$ of the teachers said to experience some type of vocal symptoms very frequently: $67.9 \%$ of them presented throat complaints (57.8\% frequently, and $10.1 \%$ always); $60.7 \%$ indicated feeling vocal fatigue (54.2\% frequently, and $6.5 \%$ always), and $54.9 \%$ of them evidenced hoarseness $(50.5 \%$ frequently, $4.4 \%$ always).

\section{Occupational Voice Profile}

Regarding vocal pattern, $81.5 \%$ of them felt some kind of muscular effort during their teaching hours, which can be graded in three levels: it was light for $16.7 \%$ of the teachers, moderate for $40.2 \%$, and high for $24.6 \%$ of them.

Significant associations were found between vocal effort and the following three types of vocal symptoms: pharyngeal paresthesias $(\mathrm{p}<0.001)$, hoarseness $(\mathrm{p}<$ $0.001)$, and phonasthenia $(\mathrm{p}<0.001)$.

\section{Prevalence of Voice Disorders}

It was found that $62.7 \%$ of the teachers were included in the UV group and were thus experiencing voice disorders to different degrees. The HV group comprised the remaining $37.3 \%$ of the subjects with no voice problems. In what follows, relations between UV teachers and psychosocial working conditions will be analyzed.

\section{Impact of Voice Disorders on Psychosocial Working Conditions}

UV teachers were exposed to worse psychosocial conditions and experienced more psychosomatic effects than their HV peers (tables 2, 3). In other words, 20 psychological dimensions out of a total of 21 dimensions were consistently affected in them. Following, those psychosocial exposure indicators associated with UV teachers will be detailed (table 2). 
Table 2. Psychosocial exposure dimensions which were significantly associated with UV teachers

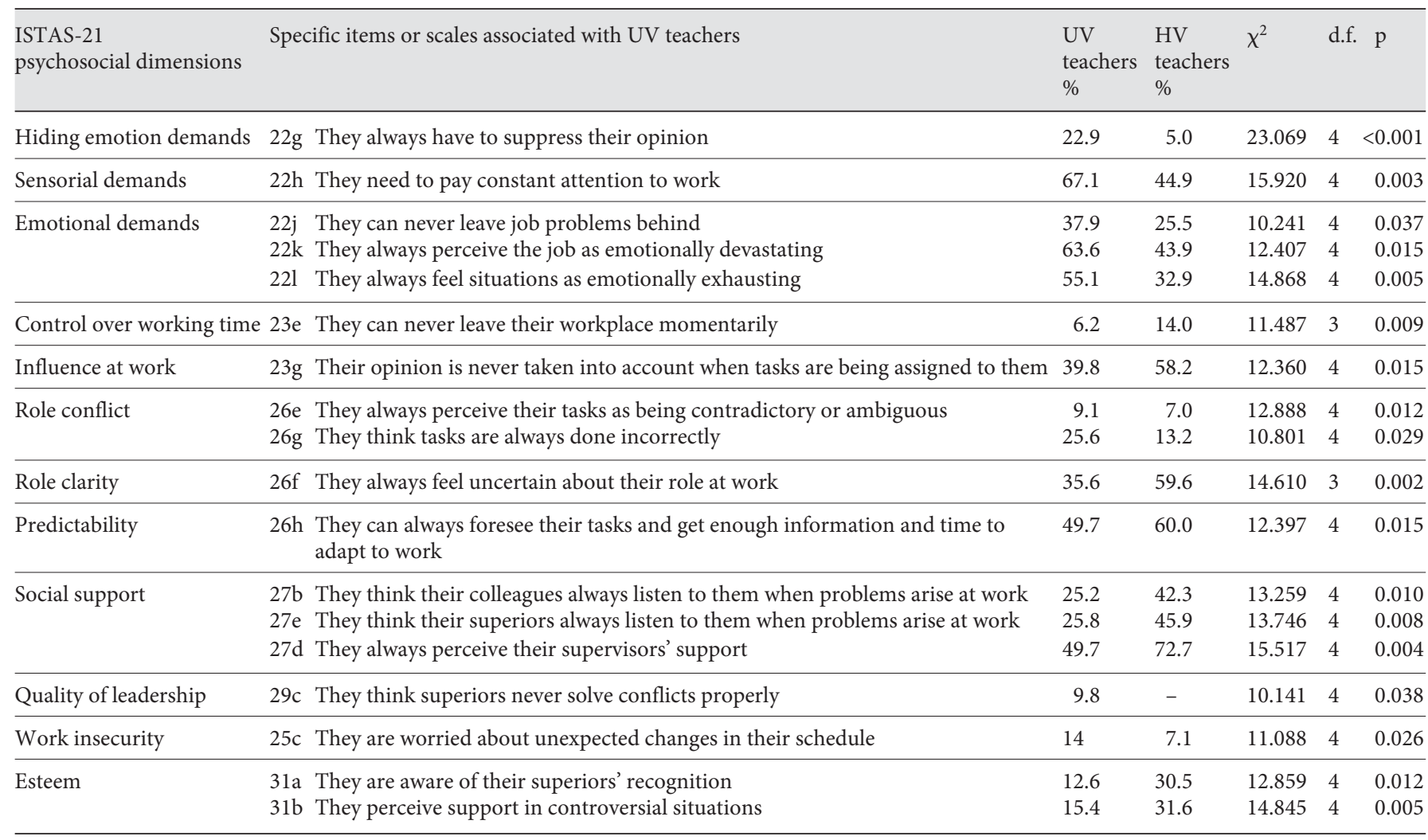

(1) The psychological demands of work category appeared to be more disturbed in UV teachers than in their $\mathrm{HV}$ colleagues, with 3 dimensions being increased. The dimension of 'hiding emotion demands' was increased in UV subjects $(p<0.000)$ because there were more UV teachers who always 'silenced their points of view' (item $22 \mathrm{~g}$ in table 2). Regarding 'sensorial demands of work', 1 item (22h) out of 4 was significantly increased in UV subjects $(\mathrm{p}<0.003)$, and it referred to their 'need for constant attention to work'. All the 3 'emotional demands' (items $22 \mathrm{j}-22 \mathrm{l}$ ) were increased in the UV group. They found it more difficult to 'leave their job problems behind' ( $\mathrm{p}<$ 0.037 ); they experienced 'emotionally exhausting situations' more frequently $(\mathrm{p}<0.015)$, and it was also more usual for them to value their job as being 'emotionally devastating' in general $(p<0.015)$. In contrast, UV teachers were not different from their HV colleagues regarding cognitive and quantitative demands.

(2) The active work and skill development category was significantly decreased in 2 dimensions. 'Working time control' was decreased $(\mathrm{p}<0.009)$ in 1 scale out of 4 (item 23e), indicating that there were fewer UV teachers who could 'leave their work place momentarily'. The 'influence at work' dimension was also decreased $(\mathrm{p}<0.015)$ in 1 out of the 4 tested items (23g): there were more UV teachers who believed that 'their opinion was not taken into account when tasks were assigned to them'.

(3) The social support category was associated with UV teachers in 5 dimensions. 'Role conflict' (items 26e, $26 \mathrm{~g}$ ) was increased because there were more UV teachers feeling that 'their tasks were ambiguous' $(\mathrm{p}<0.012)$, and also that they were 'done incorrectly' ( $p<0.029)$. The 'role clarity' dimension was decreased $(\mathrm{p}<0.002)$ in UV subjects since it was more frequent for them 'to feel uncertain as to the different aspects of their role at work' (item 26f). 'Predictability' was also diminished $(\mathrm{p}<0.015)$ as there were fewer UV teachers who could 'foresee their tasks' and 'adapt to work' (item 26h). 'Social support' deficits (items 27b, 27d, 27e) were more evident among UV teachers: it was less frequent for them 'to feel listened to' by their coworkers $(\mathrm{p}<0.010)$ and their supervisors $(\mathrm{p}<$ 0.008 ); additionally they felt 'little supported by their superiors' ( $p<0.004)$. It also occurred that only the UV teachers thought their immediate superiors 'never solved 
Table 3. Psychosomatic effect indicators which were significantly worse in UV teachers compared to their HV peers

\begin{tabular}{|c|c|c|c|c|c|c|c|}
\hline $\begin{array}{l}\text { Psychosomatic } \\
\text { effect dimensions }\end{array}$ & & Specific scales associated to UV teachers & $\begin{array}{l}\text { UV } \\
\text { teachers, \% }\end{array}$ & $\begin{array}{l}\text { HV } \\
\text { teachers, \% }\end{array}$ & $x^{2}$ & d.f. & $\mathrm{p}$ \\
\hline \multirow[t]{3}{*}{ General health } & 5 & General health is valued as bad or not so good & 16.1 & 8.1 & 11.936 & 4 & 0.018 \\
\hline & $6 b$ & Feel they are not as healthy as anyone else & 9.7 & 5.1 & 18.325 & 4 & 0.001 \\
\hline & $6 \mathrm{~d}$ & Value their health as excellent & 59.4 & 65.0 & 13.144 & 4 & 0.011 \\
\hline \multirow{2}{*}{ Mental health } & $7 \mathrm{c}$ & Feel calm (frequently/always) & 35.7 & 62 & 25.086 & 6 & $<0.001$ \\
\hline & $7 \mathrm{~d}$ & Feel downhearted or sad (frequently/always) & 11 & 8.1 & 18.030 & 4 & 0.001 \\
\hline \multirow[t]{3}{*}{ Vitality } & $7 f$ & Feel lively (frequently/always) & 16.3 & 30.3 & 11.698 & 5 & 0.039 \\
\hline & $7 g$ & Feel energetic (frequently/always) & 39 & 47.5 & 15.838 & 5 & 0.007 \\
\hline & $7 \mathrm{~h}$ & Feel exhausted (frequently/always) & 35.4 & 18.1 & 16.682 & 5 & 0.005 \\
\hline \multirow{2}{*}{$\begin{array}{l}\text { Behavioral } \\
\text { stress } \\
\text { symptoms }\end{array}$} & $8 c$ & Feel irritable (frequently) & 21.1 & 7.1 & 18.928 & 3 & $<0.001$ \\
\hline & $8 \mathrm{~d}$ & Feel overloaded (frequently) & 27.4 & 8.1 & 19.433 & 3 & $<0.001$ \\
\hline \multirow{4}{*}{$\begin{array}{l}\text { Somatic } \\
\text { stress } \\
\text { symptoms }\end{array}$} & $8 \mathrm{e}$ & Chest tightness (frequently) & 6 & 2 & 8.993 & 3 & 0.029 \\
\hline & $8 f$ & Short of breath (frequently) & 4.2 & - & 12.234 & 3 & 0.007 \\
\hline & $8 g$ & Muscular tension (frequently/always) & 21.6 & 6.1 & 28.157 & 4 & $<0.001$ \\
\hline & $8 \mathrm{~h}$ & Headache (frequently) & 50.6 & 28.3 & 25.589 & 4 & $<0.001$ \\
\hline \multirow{3}{*}{$\begin{array}{l}\text { Cognitive } \\
\text { stress } \\
\text { symptoms }\end{array}$} & $8 \mathrm{i}$ & Difficulties concentrating (frequently) & 10.3 & 2.0 & 17.973 & 3 & $<0.001$ \\
\hline & $8 \mathrm{j}$ & Difficulties taking decisions (frequently/always) & 10.2 & 3.1 & 13.744 & 4 & 0.008 \\
\hline & 81 & Difficulties thinking clearly (frequently) & 12.2 & 4.0 & 15.049 & 3 & 0.002 \\
\hline Job satisfaction & $30 c$ & $\begin{array}{l}\text { Disapprove of environmental conditions } \\
\text { (e.g. noise, ventilation, temperature) }\end{array}$ & 29.5 & 12.1 & 14.600 & 4 & 0.006 \\
\hline
\end{tabular}

conflicts properly' $(\mathrm{p}<0.038)$, which indicated a deficit in the 'quality of leadership' dimension (item 29c).

(4) Work insecurity was tested by the 'status control' and 'esteem' dimensions. Compared to the HV group the status control dimension was increased among UV teachers $(p<0.026$; item $25 c)$, which meant that it was more frequent for them 'to worry about unexpected schedule changes'. Esteem deficits were also more obvious among UV teachers in 2 out of 4 scales (items 31a, 31b): there were more UV subjects who felt 'unsatisfied with their superiors' recognition of their work' $(\mathrm{p}<0.012)$, and it was also less frequent for them 'to feel support in difficult times' $(\mathrm{p}<0.005)$.

As a consequence of the above-mentioned psychosocial conditions, UV teachers were affected by psychosomatic manifestations. Next, these effect indicators will be explained (table 3).
(1) Regarding general health perception, most of teachers considered they were healthy: $55.8 \%$ of the subjects thought their health was 'good'; $27.6 \%$ said it was 'very good', and for $3.9 \%$ of the teachers it was 'excellent'. However, both 'general health' ( $p<0.018)$ and 'mental health' $(p<0.011)$ perceptions were worse for the UV teachers in all the items or scales which were assessed (items 5, 6a, $6 \mathrm{~b}, 6 \mathrm{~d}, 7 \mathrm{a}-7 \mathrm{~d})$.

(2) Poor vitality perceptions were more frequent for the UV teachers than for their HV peers, with all the 4 scales (items $7 \mathrm{f}-7 \mathrm{i}$ ) being meaningfully affected i.e., it was more frequent for them 'to feel tired' $(p<0.001)$ or 'exhausted' ( $\mathrm{p}<0.005)$, while it was more frequent for $\mathrm{HV}$ teachers 'to feel lively' $(\mathrm{p}<0.039)$ or 'energetic' ( $\mathrm{p}<$ $0.007)$.

(3) Stress symptoms were analyzed by 12 items, and 10 of them were significantly associated with UV teachers (items $8 \mathrm{a}-8 \mathrm{j}, 8 \mathrm{l}$ ). In other words, regarding 'behavioral 
symptoms', it was more frequent for UV subjects 'to sleep uneasily' ( $p<0.044$ ), 'to prefer being left by themselves', and to be 'irritable' and 'overloaded' $(p<0.000)$. As regards 'somatic symptoms', it was more frequent for UV teachers to experience 'chest tightness' ( $p<0.029)$, 'shortness of breath' ( $p<0.007)$, 'muscular tension' and 'headache' $(p<0.000)$. Additionally, they had more frequent manifestations of 'cognitive stress' such as 'difficulties concentrating' ( $\mathrm{p}<0.000$ ), 'difficulties taking decisions' $(\mathrm{p}<0.008)$ and 'difficulties thinking clearly' $(\mathrm{p}<0.002)$.

(4) With regard to the job satisfaction dimension (item 30c), a double amount of UV teachers compared to HV teachers $(\mathrm{p}<0.006)$ were 'unsatisfied with environmental conditions such as noise, temperature, ventilation, etc'.

\section{Discussion}

As schools were geographically stratified and randomly selected, the sample depicted the variety of socioeconomic areas of the whole city district, and thus social interactions between teachers and pupils were homogeneous and comparable. Similarly to other randomized and volunteer studies, a 32\% response rate was obtained [4]. It is interesting to remark that the sample can be regarded as representative of the teachers' census because the amount of female and male teachers was equal to that of the reference population (approximately three quarters were women and one quarter men). Regarding age, subjects in the sample could also be compared with the whole population of teachers, the intervals $36-45$ years and $46-$ 55 years being the largest ones, as it occurred in the general population of teachers. Despite the well-known existence of gender and age differences in voice disorders and employment conditions, we have not analyzed these two differential factors in the present study because our aim was to evaluate the possible interactions between occupational voice disorders and psychosocial working conditions in the population of teachers as a whole.

Due to the private nature of the information requested in epidemiological studies, the use of volunteers and selfreport questionnaires is a standard practice in ethical studies on human work and communication pathology [38]. This methodology has the advantage of accounting for the workers' perception of their job environment, which may be an important determinant of their occupational health. The use of surveys has demonstrated to render reliable information about the demands of a group of people because every subjective response will be determined by the relevance that such a problem has for

Teachers' Voice Disorders and

Psychosocial Working Conditions the individual [20]. Nevertheless it has been argued that health status can influence perceptions of work characteristics (reverse causality). Additionally, the inclusion of people with negative affectivity characteristics, and a tendency to complain in general may induce spurious associations between self-report measures of both work and health [18]. However, this is not the case in this survey since most participants (87.3\%) perceived their general health state as 'quite satisfactory' or 'excellent'. It can thus be assumed that these results are not biased by either the subjects' concerns about their general health or their voice problems.

The prevalence of voice disorders in our study $(62.7 \%$ UV teachers) was higher than that found in the 1990s [21, $39,40]$, but it was similar to recent studies [2, 5, 9, 41, 42]. Therefore, it seems that voice disorders and/or teachers' awareness of them may have increased during the last decade. In any case, this increment has been observed in other works [43] and should be taken into account when evaluating the needs of this population for preventive measures.

In general, authors have used a wide range of definitions to approach the prevalence of voice disorders in epidemiological studies; i.e., voice problems may vary from subjective throat complaints to vocal fatigue and hoarseness $[25,44,45]$. Vocal complaints are usually present in most of the teaching staff and are mainly dependent upon the amount of vocal load $[5,46,47]$. Consequently, the number of symptoms as well as their frequency of appearance are the key factors to differentiate the severity of teachers' vocal complaints [3, 9, 25, 26, 43, 48]. Some authors have even shown that a voice disorder is present whenever two or more symptoms are indicated weekly or more frequently [48-50]. In this study, vocal symptoms were therefore classified regarding their number and frequency of presentation; moreover, the measure of vocal effort was added to the definition of a voice disorder to obtain a more realistic definition of a teacher with a voice problem. Since vocal effort has consistently been associated with vocal complaints $[9,10,48,49]$, it thus seems that including both factors into one variable must be operative enough to differentiate teachers with voice problems (UV people) from those whose voices are healthy (HV subjects). This definition of UV teachers also appeared to be a reliable tool to identify those subjects who were experiencing worse psychosocial conditions at work, as it is commented below.

In the employment condition context, psychosocial risk factors have been defined as the interactions between the work organization, task design, technology and job 
environment on the one hand, and the workers' functions and needs on the other [50]. In occupational health studies, the measurement of potentially stressful situations (or psychosocial exposure indicators) has been separated from the evaluation of their effects on health (which are called stress symptoms or stress in general). In order to assess exposure as well as effects of psychosocial conditions, this study followed the same conceptual models which are being used in the framework of employment condition research [51]. Before discussing our results, a brief sketch of these psychosocial models will be presented in order to better expose the interactions between voice disorders and working conditions.

Initially, a widely used model conceptualized work stress in terms of the psychological demands of work and the degree of control that employees could exert over their working conditions [16]. In general, it could be said that according to this model, work would become an excessive stressor if the worker maintained high demands and lost control. This 'demand-control' model was further developed by the addition of a third dimension, the so-called 'social support' [32, 33], which implies that employees could compensate the negative aspects of work if they received good assistance and consistent information from both colleagues and supervisors. In the last decade, two more work condition patterns were subsequently developed and other types of job compensations were also included to explain psychosocial effects. The 'effort-reward' model [17] is based on the notion of social reciprocity, and it proposes that a balanced combination of being committed to work and receiving adequate rewards is necessary for employees to maintain health. In this model, compensations involve esteem, respect, job security, promotion prospects, and financial remuneration. In a more recent 'organizational justice' model [52], the fairness of treatment concept has been included to measure the employers' impartial and truthful manner of dealing with workers, as well as their respect for their employees' viewpoints. In sum, it can be said that psychological demands, control over work, social support, and other types of compensations constitute the four basic axioms to explain the variety of psychosocial exposure indicators which can affect employees' health [53-55].

In this regard, all the above-mentioned models (demand-control, effort-reward, organizational justice) can be applied to explain UV teachers' psychosocial conditions. In the present study, it was found that UV teachers had significantly more psychological demands than their HV colleagues, specifically they were more emotionally concerned and experienced more sensorial demands.
These data are understandable since teachers' work is addressed to persons such as pupils and their families, and therefore their emotional involvement is high. Similar effects were shown in a previous study [56] which evidenced that scores in the Emotional Exhaustion Scale of the Maslach Burnout Inventory were significantly increased $(\mathrm{p}<0.001)$ among those kindergarten and elementary school teachers who used the loudest voice patterns, experienced the most severe degree of neck muscular tension, and indicated the largest amount of vocal symptoms and risk factors for voice.

With regard to dimensions related to control over work, the ISTAS-21 questionnaire measures a variety of factors, but in our study we found that UV teachers had less control than their peers over 2 dimensions, i.e. the 'time at work' and the 'type of tasks which were assigned to them'. Probably teachers with voice problems may need more time than usual to achieve their work and may also feel unable to do certain kinds of tasks because of their need to repeat or their need to rest their voice. Due to this lack of control over work, UV teachers may experience an imbalanced demand-control model of work [16], and consequently they may find diminished opportunities to develop their own professional abilities as well as to achieve an active or creative participation in their tasks.

It was also found that UV teachers experienced less compensation at work than their colleagues with no voice problems. Psychosocial dimensions such as social support, quality of leadership, job security and esteem can alleviate work strain and may play an important function as compensation mechanisms. In this regard, UV teachers showed that most aspects of the social support dimension were decreased. Compensations included in the effort-reward model and in the relational justice models were more downsized for UV teachers than for their HV colleagues. There is scientific evidence of the relevant contribution of social support to occupational health [36, 53, 55]. Furthermore, during the last decade, several authors have shown that reduced job stability and esteem have a negative effect on workers' health [17, 57, 58]. Therefore, it seems that occupational voice problems decrease work compensations, and thus UV teachers may be at a greater risk than their colleagues for psychosocial disorders.

Occurrence of the above-mentioned factors demonstrates that UV teachers were exposed to worse job organizational conditions than their peers. They were also more unsatisfied than their colleagues with environmental conditions such as noise, ventilation or temperature. As a consequence of this exposure to altered psychosocial 
conditions, they evidenced a significant impact in all the psychosomatic effects which were measured by the ISTAS-21. Specifically, UV teachers showed worse perceptions than their colleagues of both general and mental health; they also felt lower in vitality, and regarding stress symptoms they showed that behavioral, somatic, and cognitive effects were more frequent among them than in the HV group.

At present, there is a considerable amount of studies on psychosocial working conditions and health which led to the recognition of stress as a workplace hazard [59]. It is well known that stress mechanisms may induce diseases if they have enough intensity, frequency and duration so as to prevent the individual from adapting to the context demands [60]. On the one hand, stress is a wellknown precursor of straightforward related disorders at the psychological level such as emotional mechanisms (e.g. anxiety, depression) [61], cognitive reactions (e.g. decreased concentration, difficulties thinking clearly or taking decisions), behavioral disorders (e.g. insomnia, irritability, feeling weighed down with work), burnout [62], or job dissatisfaction [63]. On the other hand, stress mechanisms involve a body of associated physiologic reactions such as muscular hypertension, autonomic responses and neuroendocrine modifications [64], which can induce organic illnesses in the long term (e.g. hypertension, cardiovascular diseases, atherosclerosis, digestive ulcers, diabetes or immunological pathology or musculoskeletal disorders) $[61,65,66]$.

As voice production is partly dependent upon muscular tension, breath coordination and neuroendocrine interactions, it can be assumed that voice disorders are mediated by the same pathways as stress when voice is permanently used in tense or demanding situations [12]. Moreover, the present results indicate that voice disorders interact with psychosocial working conditions increasing stress at the workplace. However, despite this evidence there are no previous studies about associations of professional voice disorders with those psychosocial models which conceptualize stress in the employment condition framework.

Whether psychological symptoms are co-causal, precipitating or exacerbating factors for voice disorders needs to be clarified, but clinical studies have shown that psychological conditions seem to play a role in the maintenance of certain voice disorders [14]. In a recent clinical study, stress and depression were found to be more common in patients with muscle tension dysphonia than with laryngeal lesions, whereas reverse results were obtained for anxiety. Nevertheless, since individual variability in

Teachers' Voice Disorders and

Psychosocial Working Conditions the data set was large, further studies should evaluate the specific role of these conditions for selected categories of voice disorders in susceptible individuals [15]. On the other hand, our epidemiological results also indicate that teachers' voice disorders and stress can be significantly associated. Although clinical and epidemiological outcomes cannot be strictly compared, both types of methodologies resemble the multifactor association of voice disorders with both psychological and psychosocial factors.

\section{Conclusions}

Teachers who experienced frequent voice problems (62.7\%) manifested increased psychological demands (especially emotional and sensorial demands), decreased control and influence at work (decision latitude), low social support and poor job compensations. This combination of high effort and low reward dimensions can be relevant as a work stressor. Consequently, psychosomatic effects such as poor health and vitality perceptions, deficient job satisfaction and increased stress symptoms were clearly associated with voice disorders.

These data corroborate the need to address voice disorders and psychosocial conditions as occupational risk factors of the teaching context which can frequently be coexisting and interacting. Though there is an emergent body of evidence on the impact of employment conditions on health, gaps in knowledge still persist because most studies on job dimensions and health problems are descriptive, whereas empirical evidence is scarce [51]. There is also a need to study voice disorders as actual occupational risk factors. Behavioral, psychosocial and physiological approaches should assess the potential links between employment conditions and workers' health manifestations.

This knowledge will help identify and promote effective policies and institutional changes to reduce health hazards which may derive from employment conditions. How occupational health problems are understood and approached by any society is a political issue. They can be accepted as the inevitable result of individual differences, or else they can be seen as an avoidable outcome that needs to be remedied. As stated by the European Commission preventive measures at work must be programmed according to the specific demands of each task [67]. Therefore, it would be advisable for political decisions to be founded on scientific evidence so that the multifaceted interactions of occupational problems are addressed. 
Interdisciplinary work is essential to shed light on these multifactor mechanisms and effects. Crossing the boundaries of disciplines will help to take advantage of experts' knowledge and to generate new multidimensional perspectives in voice speech pathology and occupational health.

\section{Acknowledgements}

This study was financially supported by the Andalusia Public Health Service (project No. 120/04). Data collection was made possible by the assistance of the Head Office of Human Resources in the Ministry of Education of the Regional Andalusia Government, as well as by the Educational Delegate for the Malaga province. The views presented in this publication are those of the authors and do not necessarily represent the decisions, policy, or views of the above-mentioned authorities.

Appendix 1. Questions about occupational voice abuse and complaints

(A) Please indicate how frequently you are experiencing the following situations at the end of your working day:

- Do you feel your voice timbre has changed and become hoarser?

(1) Never or rarely

(2) Quite often or very often

(3) Usually or always

- Do you need to clear your throat frequently because it is dry, aching or burning?

(1) Never or rarely

(2) Quite often or very often

(3) Usually or always

- Do you feel your voice is fatigued and needs keeping in silence?

(1) Never or rarely

(2) Quite often or very often

(3) Usually or always

(B) Please indicate which of the following situations suits to you more usually:

- I need no effort at all in order to make my voice being heard in the classroom.

- I need a light effort in order to make my voice being heard in the classroom.

- I need a moderate effort in order to make my voice being heard in the classroom.

- I need a strong effort in order to make my voice being heard in the classroom.

- I do not feel any kind of vocal sensation when I am speaking in the classroom.

Appendix 2. Categories of psychosocial dimensions

\begin{tabular}{lll}
\hline Categories of psychosocial dimensions & Psychosocial dimensions & Items or scales \\
\hline Health & $\begin{array}{l}\text { general health } \\
\text { mental health }\end{array}$ & $5 ; 6 \mathrm{a}-6 \mathrm{~d}$ \\
& vitality & $7 \mathrm{a}-7 \mathrm{e}$ \\
\hline Vitality & behavioral symptoms & $7 \mathrm{f}-7 \mathrm{i}$ \\
\hline Stress symptoms & somatic symptoms & $8 \mathrm{a}-8 \mathrm{~d}$ \\
& cognitive symptoms & $8 \mathrm{e}-8 \mathrm{~h}$ \\
\hline Job satisfaction & job satisfaction & $8 \mathrm{i}-8 \mathrm{l}$ \\
\hline Psychological demands & quantitative demands & $30 \mathrm{a}-30 \mathrm{~d}$ \\
& sensorial demands & $21 \mathrm{a}-21 \mathrm{~d}$ \\
& cognitive demands & $22 \mathrm{a}-22 \mathrm{c}$ \\
& hiding emotion demands & $22 \mathrm{~d}-22 \mathrm{f}$ \\
& emotional demands & $22 \mathrm{~g}-22 \mathrm{i}$ \\
& & $22 \mathrm{j}-22 \mathrm{l}$ \\
\hline
\end{tabular}


Control over work: active work and skill development influence at work

control over time at work possibilities for development sense of work feeling of integration in the organization

Social support at work and superiors' leadership quality predictability

role clarity

role ambiguity or conflict

feedback

social support

social relation possibilities

group or community sense

leadership quality

leadership quality

status

esteem
$23 \mathrm{a}, 23 \mathrm{~b}, 23 \mathrm{~g}, 23 \mathrm{~h}$

$23 \mathrm{c}-23 \mathrm{f}$

$24 \mathrm{a}-24 \mathrm{c}, 24 \mathrm{~g}, 24 \mathrm{~h}$

$24 \mathrm{~d}-24 \mathrm{f}$

$24 \mathrm{i}-2341$

26h, 26i

$26 \mathrm{a}, 26 \mathrm{c}, 26 \mathrm{~d}, 26 \mathrm{f}$

$26 \mathrm{~b}, 26 \mathrm{e}, 26 \mathrm{~g}, 26 \mathrm{j}$

$27 \mathrm{c}, 27 \mathrm{f}$

$27 \mathrm{a}, 27 \mathrm{~b}, 27 \mathrm{~d}, 27 \mathrm{e}$

$28 \mathrm{a}, 28 \mathrm{~b}$

$28 \mathrm{c}-28 \mathrm{e}$

$29 \mathrm{a}-29 \mathrm{~d}$

$25 \mathrm{a}-25 \mathrm{~d}$

$31 \mathrm{a}-31 \mathrm{~d}$

In the ISTAS-21, indicators of effect include the following categories of dimensions: health, vitality, stress symptoms and job satisfaction. Indicators of exposure involve the following categories of dimensions: psychological demands, control over work, social support, and work insecurity. The right column shows the numbered items which assess those dimensions in the questionnaire.

\section{References}

1 Vilkman E: Occupational safety and health aspects of voice and speech professions. Folia Phoniatr Logop 2004;56:220-253.

2 Thibeault SL, Merrill RM, Roy N, Gray SD, Smith EM: Occupational risk factors associated with voice disorders among teachers. Ann Epidemiol 2004;14:786-792.

- 3 Thomas G, de Jong FICRS, Koojiman PGC, Donders ART, Cremers CWRJ: Voice complaints, risk factors for voice problems and history of voice problems in relation to $\mathrm{pu}$ berty in female student teachers. Folia Phoniatr 2006;58:305-322.

4 Kooijman PGC, de Jong FICRS, Thomas G, Huink W, Donders R, Graamans K, Schutte HK: Risk factors for voice problems in teachers. Folia Phoniatr 2006;58:159-174.

5 Bermúdez de Alvear RM, Martínez Arquero G: Factores de riesgo vocal en los docentes de Educación Infantil, Preescolar y Primaria de Málaga. Rev Esp Foniatr 2003;13:47-61.

6 Bermúdez de Alvear RM: Alteraciones de la voz; in Fundación para la Prevención de Riesgos Laborales (ed): Catálogo de enfermedades profesionales de los docentes. IS-0238/2002. Madrid, Fundación para la Prevención de Riesgos Laborales, Federación de Trabajadores de la Enseñanza de la Unión General de Trabajadores (FETE-UGT), 2004, chapt 2 , lect 1 (CD-ROM, ISBN 84-933632-0-0).

7 Wellens W, Van Opstal MJMC: Performance stress in professional voice users; in Dejonckere PH (ed): Occupational Voice: Care and Cure. The Hague, Kugler Publications, 2001, pp 81-100.

8 Sundberg J, Titze IR, Scherer R: Phonatory control in male singers: a study of the effects of subglottal pressure, fundamental fre- quency, and mode of phonation on the voice source. J Voice 1993;7:15-29.

9 Bermúdez de Alvear RM: Perfil de uso vocal en el profesorado de los colegios públicos de Málaga; PhD thesis, Málaga, 2003 (CDROM, ISBN 84-6883854-3).

10 Kooijman PGC, de Jong FICRS, Oudes MJ, Huinck W, van Acht H, Graamans K: Muscular body tension and body posture in relation to voice handicap and voice quality in teachers with persistent voice complaints. Folia Phoniatr Logop 2005;57:134-147.

11 Vilkman E, Mannimen O: Changes in prosodic features of speech due to environmental factors. Speech Commun 1986;5:331345.

$>12$ Gotaas C, Starr CD: Vocal fatigue among teachers. Folia Phoniatr 1993;45:120-129.

13 Krischke S, Weigelt S, Hoppe U, Köllner V, Klotz M, Eysholdt U, Rosanowsky S: Quality of life in dysphonic patients. J Voice 2005; 19 : 132-137.

14 de Jong FICRS, Cornelis BE, Wuyts FL, Kooijman PGC, Schutte HK, Oudes MJ, Graamans K: A psychological cascade model for persisting voice problems in teachers. Folia Phoniatr Logop 2003;55:91-101.

15 Dietrich M, Verdolini Abbot K, GartnerSmith J, Rosen CA: The frequency of perceived stress, anxiety, and depression in patients with common pathologies affecting voice. J Voice 2008;22:472-488.

16 Karasek RA: Job demands, job decision latitude and mental strain: implications for job design. Admin Sci Quart 1979;24:285-308.

17 Siegrist J: Adverse health effects of high-effort/low-reward conditions. J Occup Health Psychol 1996;1:27-41.
18 Head J, Chandola T: Case study A7; in EMCONET (ed): Final Report, 20 September 2007. http://www.emconet.org/EMCONETREPORT.pdf.

19 Junta de Andalucía: I Plan Andaluz de Salud Laboral y Prevención de Riesgos Laborales del personal docente de los Centros Públicos dependientes de la Consejería de Educación. BOJA N ${ }^{\circ} 196$, del 9 de octubre de 2006, pp 11-17.

20 Dillman DA: The design and administration of mail surveys. Annu Rev Sociol 1991;17: 225-249.

21 Smith E, Lemke J, Taylor M, Kirchner HL, Hoffman H: Frequency of voice problems among teachers and other occupations. J Voice 1998;12:480-488.

22 Rantala L, Paavola L, Körkö P, Vilkman E: Working day effects on the spectral characteristics of teaching voice. Folia Phoniatra Logop 1998;50:205-211.

23 Russell A, Oates J, Greenwood KM: Prevalence of voice problems in teachers. J Voice 1998;12:467-479.

24 Rylander R, Norrhall M, Engdahl U, Tunsäter A, Holt PG: Airways inflammation, atopy and (1-3)- $\beta$-D-glucan exposures in two schools. Am J Respir Crit Care Med 1998; 158:1685-1687.

25 Jónsdottir VI, Boyle BE, Martin PJ, Sigurdardottir G: A comparison of the occurrence and nature of vocal symptoms in two groups of Icelandic teachers. Logoped Phoniatr Vocol 2002;27:98-105.

26 Preciado J, Pérez C, Calzada M, Preciado P: Incidencia y prevalencia de los trastornos de la voz en el personal docente de La Rioja. Acta Otorrinolaringol Esp 2005;56:202-210. 
27 Moncada S, Llorens C, Kristensen TC: Método ISTAS-21 (CoPsoQ). Manual para la evaluación de riesgos psicosociales en trabajo. Madrid, Instituto Sindical de Trabajo, Ambiente y Salud (ISTAS), 2004.

28 Kristensen TS, Borg V: Copenhagen Psychosocial Questionnaire (COPSOQ). A questionnaire on psychosocial working conditions, health and well-being in three versions. Copenhagen, National Institute of Occupational Health, 2003.

29 Generalitat de Catalunya: Identificació i avaluació de riscos psicosocials. Manual de la versió mitjana del mètode PSQCAT-21 COPSOQ (Qüestionari psicosocial de Copenhaguen) adaptat; in Departament de Treball i Indústria (ed): Manual per a la identificació i avaluació de riscos laborals. Barcelona Departament de Treball i Indústria, 2005, pp 155-202. http://www.gencat.net/treballiindustria/relacions_laborals/seguretatisalut/ manual_riscos/psqcat21/index.html.

30 Moncada S, Llorens C, Navarro A, Kristensen TS: ISTAS-21: versión en lengua castellana del cuestionario psicosocial de Copenhague (COPSOQ). Arch Prev Riesgos Labor 2005;8:18-29.

31 Moncada S, Llorens C, Kristensen TS, Vega S: El método COPSOQ (ISTAS-21, PSQCAT21) de evaluación de riesgos psicosociales. Nota técnica de prevención número 703. Madrid, Instituto Nacional de Seguridad e Higiene en el Trabajo, 2006.

32 Karasek R, Theorell T: Healthy Work-Stress, Productivity and the Reconstruction of Working Life. New York, Basic Books, 1990.

33 Karasek RA: Job socialisation and job strain the implications of two psychosocial mechanisms for job design; in Gardell B and Johansson G (eds): Working Life: A Social Science Contribution to Work Reform. Chichester, Wiley \& Sons, 1981.

34 Johnson JV, Hall EM: Social support in the work environment and cardiovascular disease; in Shumaker S, Czajkowski S (eds): Social Support and Cardiovascular Disease. New York, Plenum Press, 1995.

- 35 Siegrist J, Starke D, Chandola T, Godin I, Marmot M, Niedhammer I, et al: The measurement of effort-reward imbalance at work: European comparisons. Soc Sci Med 2004;58:1483-1499.

-36 Vilagut G, Ferrer M, Rajmil L, Rebollo P, Permanyer-Miralda G, Quintana JM, Santed R, Valderas JM, Ribera A, Domingo-Salvany A, Alonso J: El cuestionario de salud SF-36 español: una década de experiencia y nuevos desarrollos. Gac Sanit 2005;19:135-150.

-37 Setterlind S, Larsson G: The stress profile: a psychosocial approach to measuring stress. Stress Med 1995; 11:85-92.

38 Bernstorf ED, Burk KW: Vocal integrity of elementary vocal music teachers: personal and environmental factors. J Res Music Educ 1996;44:369-383

- 39 Sapir S, Keidar A, Mathers-Schmidt B: Vocal attrition in teachers: survey findings. Eur J Disord Commun 1993;28:177-185.
40 Morton V, Watson DR: The teaching voice: problems and perceptions. Logoped Phoniatr Vocol 1998;23:133-139.

41 Yiu E: Impact and prevention of voice problem in the teaching profession: embracing the consumers' view. J Voice 2002;16:215-228.

42 Sliwinska-Kowalska M, Niebudek-Bogusz E, Fiszer M, Los-Spychalska T, Kotylo P, Sznuroeska-Przygocka $\mathrm{B}$, Modrzewska $\mathrm{M}$ : The prevalence and risk factors for occupational voice disorders in teachers. Folia Phoniatr Logop 2006;58:85-101.

43 Simberg S, Sala E, Ronnemaa AM: A comparison of the prevalence of vocal symptoms among teacher students and other university students. J Voice 2004;18:363-368.

44 Rantala L, Vilkman E, Bloigu R: Voice changes during work: subjective complaints and objective measurements for females primary and secondary schoolteachers. J Voice 2002;16:344-355.

45 Sarfati J, Epron JP: Evaluation of vocal abuse by the patient and correlation with vocal cords lesions. Rev Laryngol Otol Rhinol 2003; 124:345-348.

46 Vintturi J, Alku P, Sala E, Sihvo M, Vilkman E: Loading-related subjective symptoms during vocal loading test with special reference to gender and some ergonomic factors. Folia Phoniatr Logop 2003;55:55-69.

47 Simberg S, Sala E, Vehmas K, Laine A: Changes in the prevalence of vocal symptoms among teachers during a twelve-year period. J Voice 2005; 19:95-102.

48 Sala E, Laine A, Simberg S, Pentti J, Suonpää $\mathrm{J}$ : The prevalence of voice disorders among day care center teachers compared with nurses: a questionnaire and clinical study. J Voice 2001;15:413-423.

49 Simberg S, Laine A, Sala E, Ronnemaa AM: Prevalence of voice disorders among future teachers. J Voice 2000;14:231-235.

50 Comisión de las Comunidades Europeas: Cómo adaptarse a los cambios en la sociedad y en el mundo del trabajo. Bruselas, Estrategia Comunitaria de Salud y Seguridad en el Trabajo, 2002.

51 Kalimo R, Lindström K, Smith MJ: Psychosocial approach in occupational health; in Salvendy G (ed): Handbook of Human Factors and Ergonomics, ed 2. New York, Wiley \& Sons, 1997.

52 Benach J, Muntaner C, Santana V: Employment Conditions and Health Inequalities: Final Report to the Commission on Social Determinants of Health (CSDOH). Employment Conditions Network (EMCONET) Geneva, WHO, 2007. Available from http:// www.who.int/social_determinants/knowledge_networks/employment/en/index. html, accessed on July 14, 2009.

53 Elovainio M, Kivimäki M, Vahtera J: Organizational justice: evidence of a new psychosocial predictor of health. Am J Public Health 2002;92:105-108.
54 Moncada S, Llorens C: Evaluación del riesgo psicosocial: el método ISTAS-20 (CoPsoQ). $3^{\circ}$ foro ISTAS de salud laboral. 2002 27-29 nov. Palma de Mallorca, Paralelo Ed SA, 2003, pp 87-95.

55 The European Heart Network: Expert Group on Psychosocial and Occupation Factors. Social Factors, Stress and Cardiovascular Disease Prevention in the European Union. Brussels, European Heart Network, 1998.

56 Moncada S, Artazcoz L: Factores psicosociales; in Benavides FG, Ruiz-Frutos C, García AM (eds): Salud Laboral, ed 2. Barcelona, Masson, 2000.

57 Bermúdez de Alvear RM, Martínez Arquero G, Rius Díaz F, Esteve Zarazaga JM: Relaciones entre el uso de la voz y el nivel de estrés en los docentes de Educación Infantil y Primaria de Málaga. Rev Esp Pedagog 2004;227: $85-102$.

58 Siegrist J: Chronischer Distress und koronares Risiko: Neue Erkenntnisse und ihre Bedeutung für die Pravention; in Arnold M, Ferber CV, Henke KD (eds): Ökonomie der Prävention. Gerlingen, Bleicher, 1990.

59 Peter R, Siegrist J: Chronic work stress, sickness absence and hypertension in middle managers: general or specific sociological explanations? Soc Sci Med 1997;45:111-120.

60 Benavides FG, Benach J, Muntaner C: Psychosocial risk factors at the workplace: is there enough evidence to establish reference values? J Epidemiol Commun Health 2002; 56:244-245.

61 Simberg S, Sala E, Laine A, Ronnemaa AM: A fast and easy screening method for voice disorders among teacher students. Logoped Phoniatr Vocol 2001;26:10-16.

62 Mausner-Dorsch H, Eaton W: Psychosocial work environment and depression: epidemiologic assessment of the demand-control model. Am J Public Health 2000;90:1765-1770.

63 Ahola K, Honkonen T, Kivimaki M, Virtanen $\mathrm{M}$, Isometsa $\mathrm{E}$, Aromaa $\mathrm{A}$, et al: Contribution of burnout to the association between job strain and depression: the Health 2000 Study. J Occup Environ Med 2006;48: 1023-1030.

64 Stansfeld S, Candy B: Psychosocial work environment and mental health - A meta-analytic review. Scand J Work Environ Health 2006;32:443-462.

65 Schneider B, Enne R, Cecon M, DiendorferRadner G, Wittels P, Bigenzahn W, Johannes $B$ : Effects of vocal constitution and autonomic stress-related reactivity on vocal endurance in female student teachers. J Voice 2006;20:242-250.

66 Kumari M, Head J, Marmot M: Prospective study of social and other risk factors for incidence of type 2 diabetes in the Whitehall II study. Arch Intern Med 2004;164:1873-1880.

67 Council Directive: On the Introduction of Measures to Encourage Improvement in the Safety and Health of Workers at Work. 89/391/EEC. Brussels, 1989. 